http://dx.doi.org/10.18778/1508-1117.25.07

Łukasz Musiaka

\title{
PERCEPCJA MATERIALNEGO DZIEDZICTWA ZAKONU KRZYŻACKIEGO NA PRZYKŁADZIE PUCKA
}

\begin{abstract}
Zarys treści Jednym $\mathrm{z}$ ważnych miejsc na mapie dawnego państwa krzyżackiego nad Bałtykiem był Puck. Do dzisiaj zachowały się tam fara, ruiny zamku krzyżackiego oraz doskonale widoczny układ przestrzenny miasta lokacyjnego z dużym rynkiem. Elementy średniowiecznego dziedzictwa kulturowego pełnią dziś ważną rolę w promocji miasta, jak również w kształtowaniu poczucia dumy i patriotyzmu lokalnego mieszkańców. W artykule autor podjął próbę określenia poziomu wiedzy osób mieszkających na terenach dawnego państwa zakonnego na temat historii i materialnej spuścizny kulturowej zakonu krzyżackiego. Podstawę prowadzonych analiz stanowiły wyniki badań ankietowych zrealizowanych w Pucku w maju 2015 roku.
\end{abstract}

Słowa kluczowe Percepcja, dziedzictwo kulturowe, zakon krzyżacki, Puck.

\section{Wprowadzenie}

W średniowieczu Zakon Szpitala Najświętszej Maryi Panny Domu Niemieckiego w Jerozolimie drogą nadań, kupna, zbrojnych podbojów i działalności dyplomatycznej utworzył u południowych wybrzeży Morza Bałtyckiego potężne państwo zakonne. Obecność zakonników na tych terenach trwała od XIII do XVI wieku, kiedy to dokonano sekularyzacji zakonu krzyżackiego. Na terytorium państwa zakonnego powstała w tym czasie gęsta sieć 96 miast lokacyjnych oraz ponad 1400 wsi. Trwałym śladem dawnej organizacji państwowej są również pozostałości ponad 100 zamków warownych, umocnień miejskich, szereg kościołów i innych budynków użyteczności publicznej (Musiaka 2015). Jednym z ważniejszych miejsc na mapie państwa zakonnego był Puck. Najstarsza wzmianka o mieście pochodzi z 1220 roku. Na jej podstawie możemy stwierdzić, że Puck był wsią, w której organizowane były targi. Wieś nadana przez pomorskiego księcia Sambora należała do cystersów z Oliwy, później miejscowość zakonnikom odebrano. Zdaniem B. Śliwińskiego (1998), w Pucku znajdował się również gród 
stanowiący centrum lokalnego opola, w okresie późniejszym gdańskiej kasztelanii. W 1311 roku, po zajęciu Pomorza Gdańskiego przez Krzyżaków, Puck włączono do komturstwa gdańskiego, a urzędnik rezydujący w zamku puckim piastował godność rybickiego puckiego, czyli urzędnika odpowiedzialnego za dostarczanie ryb do państwa zakonnego, ale również za administrowanie podległym mu okręgiem. Puck uzyskał prawa miejskie chełmińskie 16 listopada 1348 roku (Grzegorz 2014, s. 25). Miasto otrzymało prawo połowu ryb w Bałtyku i Zatoce Puckiej. W 1440 roku mieszczanie puccy złożyli deklarację przystąpienia do Związku Pruskiego (Grzegorz 2014, s. 26). Doprowadziło to do przejęcia przez związkowców kontroli nad zamkiem Puckim w 1454 roku.

Z czasem miasto znalazło się pod silnym wpływem Rady Miejskiej Gdańska. Ciekawe wydarzenie miało miejsce w 1457 roku, kiedy to w mieście schronił się król Szwecji Karol Knutson Bonde, który poszukiwał pomocy w walce z duńskim królem Chrystianem o odzyskanie tronu (Kruppe, Milewska 2014, s. 18). Mieszczanie gdańscy pożyczyli znaczną kwotę pieniędzy od szwedzkiego uciekiniera, za co ten otrzymał pod zastaw okręg pucki i łebski. Karol Knutson Bonde rezydował w mieście przez trzy lata. W 1460 roku, na okres czterech lat, Puck zajmują Krzyżacy i lokują tu swoją bazę kaperską. Po tych wydarzeniach miasto stało się siedzibą królewskiego starostwa. Pod panowaniem polskim Puck został siedzibą polskiej floty kaperskiej i był ważnym punktem w zbrojnych rozgrywkach na Bałtyku między Rzeczpospolitą a Danią i Szwecją. W 1772 roku miasto, w wyniku pierwszego rozbioru, przechodzi pod panowanie pruskie. W tym czasie zamek stopniowo podupadał. Na jego terenie w 1845 roku poświęcono luterański kościół. Budowla przetrwała do 1958 roku, kiedy to została zburzona i rozebrana celem pozyskania materiałów budowlanych i budowy na jego miejscu zakładu produkcyjnego (Kruppe, Milewska 2014, s. 24). Przypuszczalny wygląd zamku w okresie krzyżackim przedstawia rys. 1, a współczesny wygląd terenu zamku prezentuje fot. $1 \mathrm{~A}$. Obecna funkcja turystyczna zamku puckiego jest bardzo ograniczona. W ostatnim czasie pojawiły się plany lokalnego samorządu, aby dokonać rekonstrukcji zamku ${ }^{1}$ na podstawie danych zebranych w wyniku prac archeologicznych prowadzonych od 1991 roku przez Instytut Archeologii Uniwersytetu Warszawskiego wspólnie z Instytutem Archeologii i Etnologii Polskiej Akademii Nauk w Warszawie. W okresie uzyskania praw miejskich (1348) najprawdopodobniej przystąpiono do otoczenia miasta murami obronnymi (Sypek, Sypek 2003, s. 111). Do czasów obecnych żaden fragment murów nie ocalał oprócz niewielkiego zagłębienia, śladu po fosie w północno-wschodniej części miasta lokacyjnego. W zupełnie odmiennej kondycji technicznej znajduje

${ }^{1} \mathrm{http}: / /$ strefahistorii.pl/article/1391-w-pucku-zaplanowano-odbudowe-zamku-bazy-floty-zygmunta-iii. 
się pucka fara. Obecny kościół pw. św. Piotra i Pawła (fot. 1C), według źródeł pochodzi sprzed XIV wieku. Powstał on na miejscu wcześniejszej świątyni, która ufundowana była jeszcze w wieku XII, co stawia parafię pucką w rzędzie najstarszych na Pomorzu Wschodnim (Kruppe, Milewska 2014, s. 16). Doskonale jest również zachowany układ przestrzenny miasta lokacyjnego z dużym rynkiem (fot. 1B), który został wpisany do rejestru zabytków. Jak podaje M. Grzegorz (2014, s. 25), „W mieście powinno być 100 działek o łącznej długości 7 prętów i szerokości 3 prętów". Obecne wymiary rynku wynoszą 110 x 43 metry (Starski 2011, s. 150).

Do pozostałych elementów dziedzictwa kulturowego w Pucku, które zostały wpisane do rejestru zabytków należą: cztery domy z połowy XIX wieku, dawny „Zajazd pod Lwem” i hotel „Kaszubski” z XIX wieku, obecnie domy mieszkalne, dwór przy ul. Przebendowskiego oraz dawny szpital pw. św. Jerzego z XVIII wieku. W budynku tzw. szpitalika i kamienicy przy pl. Wolności 28 mieści się Muzeum Ziemi Puckiej im. Floriana Ceynowy.

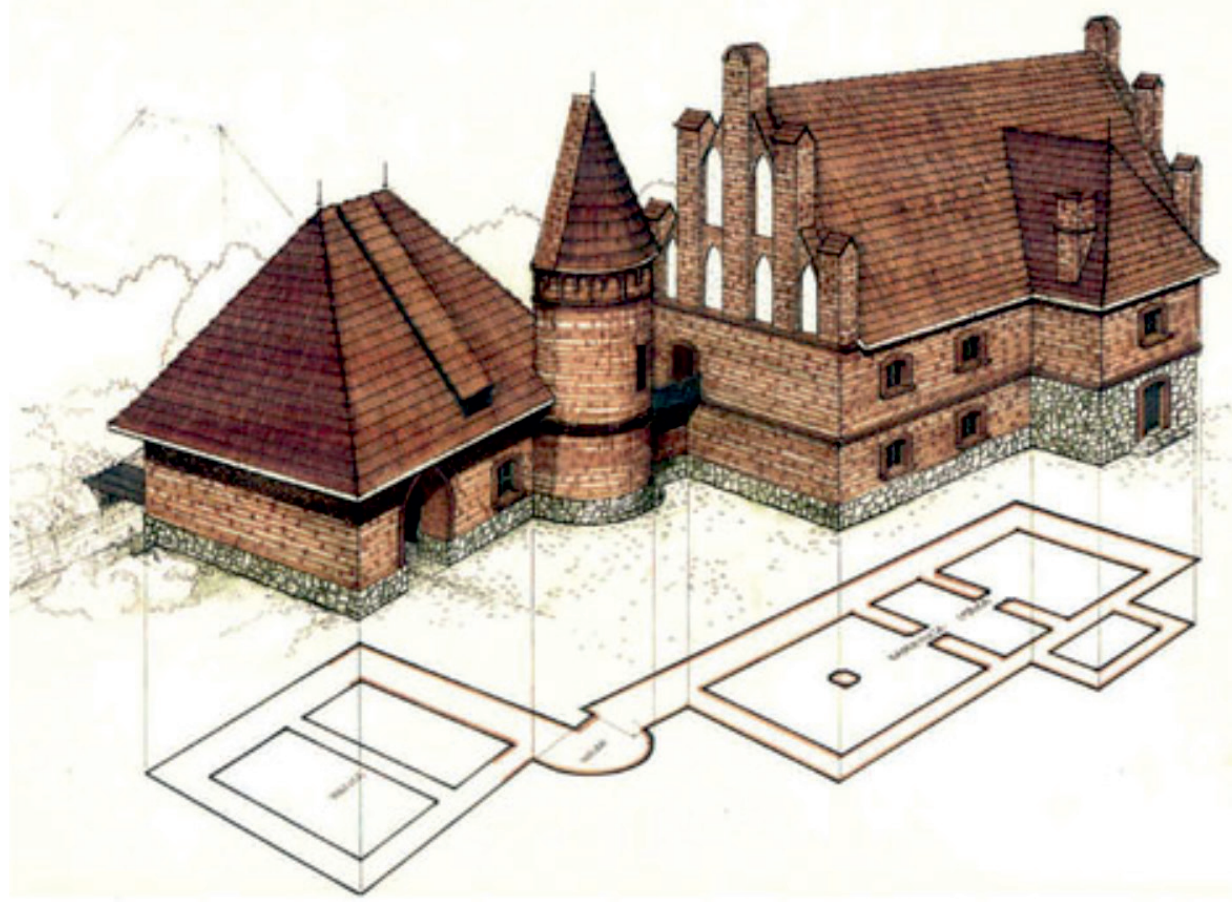

Rys. 1. Rekonstrukcja domu wójta krzyżackiego w Pucku według Milewskiej, Zborowskiej i Kruppe

Źródło: http://www.puck.uw.edu.pl/ 

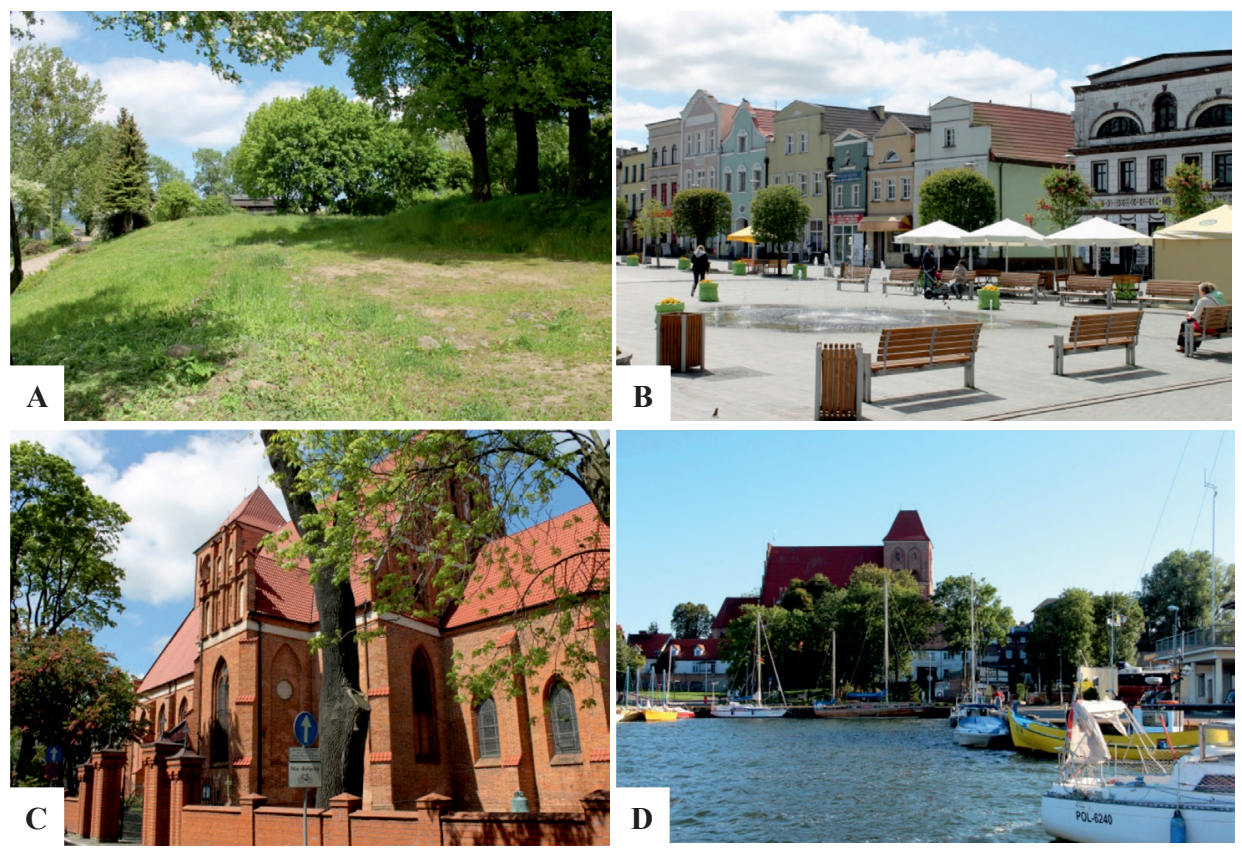

Fot. 1. Elementy średniowiecznego dziedzictwa kulturowego w Pucku A - ruiny zamku krzyżackiego, B - fragment zachodniej pierzei rynku lokacyjnego, C - fara w Pucku pw. Św. Apostołów Piotra i Pawła, D - widok na miasto od strony portu fot. E. Musiaka

\section{Przedmiot, cel oraz metody badań}

Przedmiotem badań była percepcja respondentów dotycząca dwóch grup zagadnień związanych z zakonem krzyżackim i jego dziedzictwem. Pierwsza grupa pytań dotyczyła historii zakonu krzyżackiego, atrakcyjności turystycznej i wykorzystania materialnego dziedzictwa zakonu, które przetrwało na obszarze dawnego państwa zakonnego we współczesnych granicach Polski. Druga grupa pytań, posiadająca silny rys regionalny, dotyczyła znajomości historii zakonu w Pucku i jego spuścizny materialnej.

Podstawowym celem badania było uzyskanie informacji dotyczących poziomu wiedzy mieszkańców Pucka na temat dziedzictwa zakonu krzyżackiego, sposobów i możliwości jego wykorzystania. Kolejnym celem było określenie poziomu wiedzy i świadomości historycznej mieszkańców i poczucia ich patriotyzmu lokalnego.

Informacje niezbędne do realizacji założeń badawczych dzieli się na pierwotne i wtórne (Altkorn 1994, s. 177). Dane pierwotne, które uzyskuje się za pomocą badań terenowych (field research) zostały zebrane przez odpowiednio poinstruowanych i przeszkolonych studentów drugiego roku studiów licencjackich 
kierunku Studia Regionalne na Wydziale Nauk Geograficznych Uniwersytetu Łódzkiego, w ramach ćwiczeń terenowych „Działalność człowieka w regionie”. W badaniach terenowych wzięło udział 12 studentów, podzielonych na dwuosobowe zespoły. Zebranie i wstępną analizę pozyskanego materiału badawczego powierzono kolejnym dwóm osobom. Zastosowano metodę badań ankietowych i technikę ankiety. Przeprowadzone badania mają charakter pilotażowy i należy traktować je jedynie jako wstęp do pogłębionych analiz zagadnienia percepcji dziedzictwa zakonu krzyżackiego w Polsce. Pomimo tego, stosunkowo duża ilość zebranych kwestionariuszy ogółem $(\mathrm{n}=257)$, pozwala określić przeprowadzone badania jako wartościowe. Oprócz zastosowania metody badań ankietowych, dokonano również analizy źródeł zastanych (dostępnych źródeł wtórnych), inaczej określanej jako desk research.

W ramach ćwiczeń studenci zapoznali się z historią i dziedzictwem zakonu krzyżackiego oraz zrealizowali badania ilościowe w Pucku w dniach 25 i 26 maja (poniedziałek i wtorek) 2015 roku. Kwestionariusze ankiety były wypełniane w godzinach od $10^{00}$ do $14^{00}$. Podstawą zaliczenia ćwiczeń terenowych przez studentów było poprawne przeprowadzenie badań kwestionariuszowych, sporządzenie bazy danych w programie Excel oraz analiza wyników przedstawiona w postaci raportu. Autor artykułu był pomysłodawcą i opiekunem przeprowadzonych badań.

Dobór próby badawczej należy określić jako dostępnościowy prosty. Polega on na bezpośrednim i nieograniczonym pozyskiwaniu badanych jednostek (Babbie 2003, s. 204). Ze względu na to, że nie każda napotkana przez ankieterów osoba mogła wziąć udział w badaniu (zbyt młody wiek, miejsce zamieszkania i in.), wybór respondentów można określić inaczej jako nielosowy. Polega on na tym, że „dobór jednostek próby uzależniony jest od osoby prowadzącej badanie. Jest to więc wybór subiektywny, uzależniony od wiedzy i poglądów prowadzącego badanie" (Wasilewska 2008, s. 30). Wiek, rodzaj wykonywanej pracy i inne czynniki charakteryzujące respondentów, w pewnym stopniu były konsekwencją metody doboru próby. Dotyczy to przede wszystkim kwestionariuszy przeprowadzanych w Liceum Ogólnokształcącym oraz w Urzędzie Miasta. W przypadku większości badanej populacji (81\%) wybór ankietowanych był zróżnicowany. Ze względu na nieprobabilistyczny dobór próby, uzyskanych wyników nie można uogólniać na całą populację mieszkańców Pucka. W wyniku zastosowanej metody nie ma również możliwości oceny popełnianego błędu przy doborze respondentów (Wasilewska 2008, s. 30). Z racji ograniczonego czasu badania i dużej liczby mieszkańców Pucka (11317 osób w 2015 roku) ${ }^{1}$ zastosowanie losowego doboru próby nie było możliwe.

Kwestionariusze ankiety były zbierane w następujących miejscach w Pucku: rynek i obszar starego miasta, Urząd Miejski, Liceum Ogólnokształcące im. Stefana

\footnotetext{
${ }^{1}$ http://www.polskawliczbach.pl/.
} 
Żeromskiego w Zespole Szkół Ogólnokształcących oraz na terenie na południe od ul. Wejherowskiej, na obszarze ogródków działkowych i w ich sąsiedztwie (rys. 2). W Urzędzie Miasta respondentami byli pracownicy, a w liceum - uczniowie szkoły.

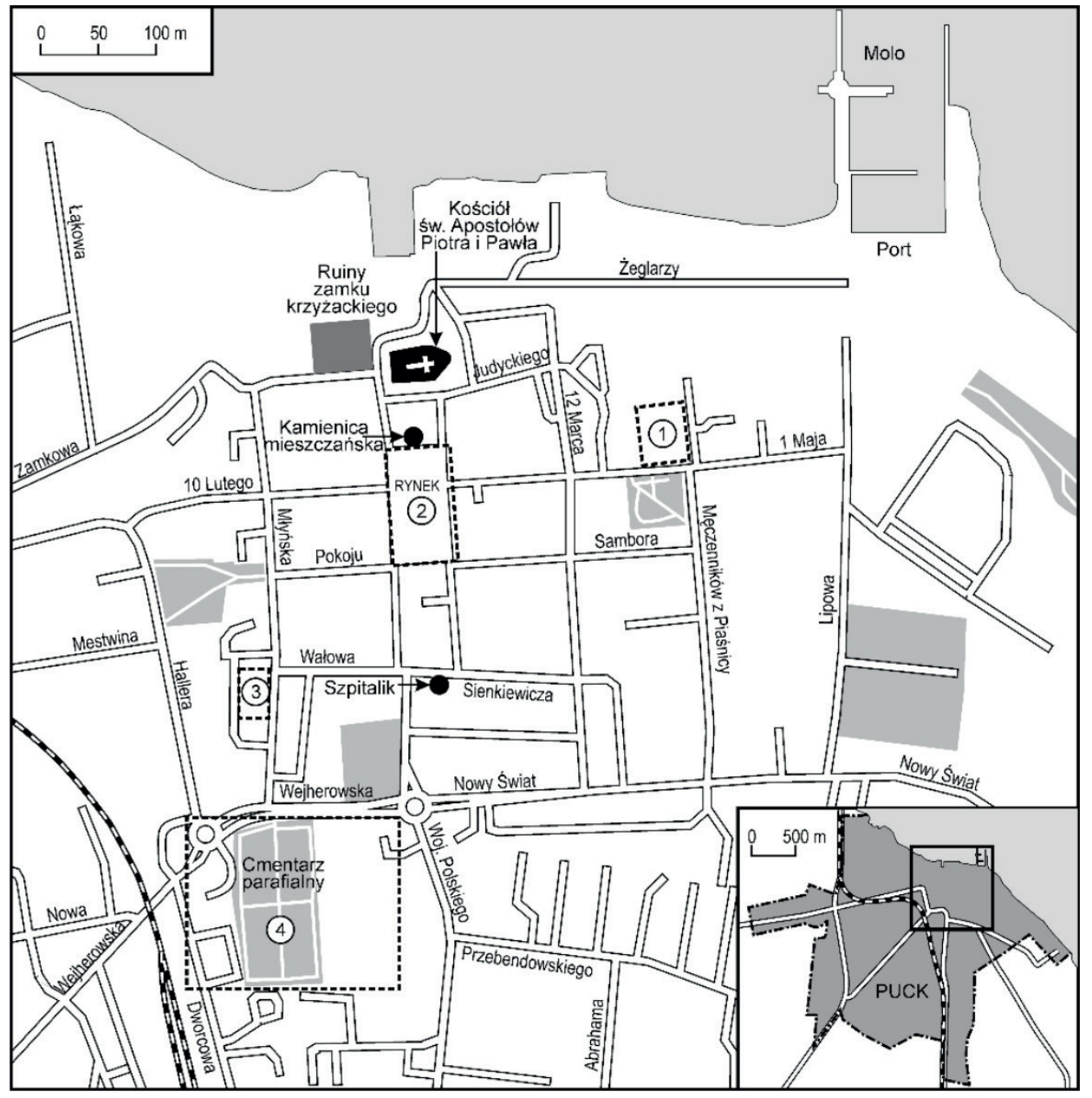

Rys. 2. Obszar realizacji badań ankietowych w Pucku Źródło: opracowanie własne

Kwestionariusz ankiety składał się z 13 pytań dotyczących historii i dziedzictwa zakonu krzyżackiego, w tym 4 pytania dotyczące Pucka oraz metryczka. W kwestionariuszu wykorzystano głównie pytania otwarte, jedno pytanie zamknięte oraz dwa pytania wartościujące, gdzie respondenci udzielali odpowiedzi według skali ocen od 1 do 5 . 


\section{Charakterystyka badanej zbiorowości}

Głównym czynnikiem, który wzięto pod uwagę podczas planowania procesu badawczego, było miejsce zamieszkania respondentów. Osoby mieszkające w Pucku, bądź silnie z nim związane, to jest dojeżdżające do pracy, szkoły lub $\mathrm{w}$ celu skorzystania $\mathrm{z}$ innych usług $\mathrm{w}$ mieście $\mathrm{z}$ okolicznych terenów, uznano za podmiot badań. Spośród grupy 257 respondentów, 5\% ankietowanych stanowili pracownicy Urzędu Miasta, a 14\% - uczniowie Liceum Ogólnokształcącego. Najliczniejszą grupę, $81 \%$ badanych, stanowili pozostali mieszkańcy miasta i okolic, w tym $49 \%$ osób dojeżdżających. Blisko połowa respondentów, którzy mieszkają poza miastem, wynika w dużej mierze ze znacznej liczby uczniów pochodzących z okolicznych miejscowości oraz osób dojeżdżających do pracy, na zakupy i w innych celach. Puck jest miastem powiatowym i stanowi lokalne centrum usług społecznych i komercyjnych. Odsetek osób mieszkających od urodzenia $\mathrm{w}$ mieście koresponduje $\mathrm{z}$ ich wiekiem. Jedynie 3\% ankietowanych mieszka w Pucku poniżej 5 lat. W badanej grupie dominowały kobiety (57\%) nad mężczyznami (43\%). Struktura wieku respondentów przedstawia się następująco: $39 \%$ to osoby młode w wieku poniżej 20 lat (znaczny odsetek uczniów badanej szkoły oraz młodzieży szkolnej z innych placówek), 17\% osób w przedziale wiekowym 21-30 lat, 14\% w wieku 31-40 lat, 9\% w przedziale 41-50 lat, $10 \% \mathrm{w}$ wieku 51-60 lat i 11\% powyżej 61. roku życia.

Wśród ankietowanych aż $68 \%$ to osoby aktywne zawodowo. W przypadku osób nieaktywnych zawodowo ( $32 \%$ respondentów), osoby bezrobotne stanowią $52 \%$, emeryci $27 \%$, a renciści $21 \%$. Znaczny odsetek bezrobotnych w badanej grupie nieaktywnych zawodowo wynika $\mathrm{z}$ wieku respondentów, są to w dużej mierze osoby młode, które nie podjęły jeszcze działalności zarobkowej. Struktura wykształcenia badanej grupy wygląda następująco: $45 \%$ osób z wykształceniem średnim, 17\% osób z wykształceniem zawodowym, 20\% z wykształceniem gimnazjalnym, $6 \%$ osób z wykształceniem wyższym magisterskim, $5 \%$ z wykształceniem policealnym, $4 \%$ z wykształceniem podstawowym i 3\% z wykształceniem podyplomowym.

\section{Wiedza respondentów na temat zakonu krzyżackiego}

Pierwsze pytanie, na które musieli odpowiedzieć respondenci brzmiało następująco: „Czy zakon krzyżacki nadal istnieje?” Niecała połowa, czyli 46\% ankietowanych odpowiedziała negatywnie. Trzydzieści cztery procent badanych nie potrafiło udzielić odpowiedzi, a jedynie $20 \%$ osób odpowiedziało zgodnie z prawdą, że zakon krzyżacki cały czas istnieje i funkcjonuje. Taki rozkład odpowiedzi spowodowany jest małym zainteresowaniem zakonem krzyżackim oraz traktowaniem Krzyżaków w kategoriach historycznych. Poprawną odpowiedź udzielała 
głównie młodzież szkolna, oraz osoby zainteresowane historią regionu i historią zakonu, które swoją wiedzę czerpią w dużej mierze z przekazów medialnych.

$\mathrm{W}$ drugim, rozbudowanym pytaniu, ankietowani mieli udzielić odpowiedzi, w którym wieku i w którym roku miały miejsce następujące wydarzenia: powstanie zakonu krzyżackiego, sprowadzenie zakonu do Polski, sekularyzacja państwa zakonnego. Prawidłowe daty, według kolejności to: 1198 r. (zatwierdzenie działalności zakonu), 1226 r., 1525 r. Ankieterzy zaliczali prawidłową odpowiedź w przypadku podania dokładnego roku lub pomyłki o 1-2 lata. W przypadku pytania o wiek wydarzenia, zaliczano tylko precyzyjną odpowiedź. Rozkład odpowiedzi ilustruje tab. 1. Respondenci na wymienione pytania odpowiadali podobnie, zdecydowana większość nie znała ani roku, ani wieku, kiedy rozgrywały się wspomniane wydarzenia. Zakres prawidłowych odpowiedzi wahał się w granicach od $9 \% \mathrm{w}$ przypadku roku sekularyzacji zakonu do $20 \% \mathrm{w}$ pytaniu o wiek powstania zakonu krzyżackiego.

Tabela 1

Odsetki odpowiedzi respondentów na pytanie nr 3, dotyczące ważnych wydarzeń z dziejów zakonu krzyżackiego

\begin{tabular}{|l|c|c|c|}
\hline \multirow{2}{*}{\multicolumn{1}{|c}{ Treść pytania }} & \multicolumn{3}{|c|}{ Odpowiedź (\%) } \\
\cline { 2 - 4 } & Prawidłowa & Nieprawidłowa & Brak \\
\hline Wiek powstania zakonu & 20 & 20 & 60 \\
\hline Rok powstania zakonu & 13 & 18 & 69 \\
\hline $\begin{array}{l}\text { Wiek sprowadzenia zakonu } \\
\text { do Polski }\end{array}$ & 13 & 26 & 61 \\
\hline $\begin{array}{l}\text { Rok sprowadzenia zakonu } \\
\text { do Polski }\end{array}$ & 11 & 20 & 69 \\
\hline $\begin{array}{l}\text { Wiek sekularyzacji państwa } \\
\text { zakonu krzyżackiego }\end{array}$ & 11 & 20 & 69 \\
\hline $\begin{array}{l}\text { Rok sekularyzacji państwa } \\
\text { zakonu krzyżackiego }\end{array}$ & 9 & 16 & 76 \\
\hline Razem & 100 & 100 & 100 \\
\hline
\end{tabular}

Źródło: opracowanie własne na podstawie wyników badań ankietowych.

Najwięcej poprawnych odpowiedzi uzyskano w grupie osób starszych i z wyższym wykształceniem. Rozkład uzyskanych odpowiedzi na pytanie trzecie należy uznać za niezadowalający i wskazujący na niską wiedzę historyczną ankietowanych. Szczególnie zastanawiający jest fakt dużej liczby nieprawidłowych odpowiedzi bądź ich braku w grupie młodzieży szkolnej. 
Kolejne pytanie dotyczyło dowolnych skojarzeń związanych z zakonem krzyżackim. Respondenci mogli podać od jednego do czterech skojarzeń. Łączna suma wszystkich skojarzeń, które mogli wymienić respondenci i która była podstawą wyliczenia struktury procentowej odpowiedzi, wynosi 1028 . Rozkład procentowy udzielonych odpowiedzi zaprezentowano na rys. 3. Siedmiu procentom ankietowanych zakon krzyżacki z niczym się nie kojarzy, a ponad połowa (53\%) badanych osób, nie była w stanie podać czterech skojarzeń. Do najczęściej wymienianych skojarzeń należały: symbole zakonu krzyżackiego (np. czarny krzyż na białym płaszczu, zbroja, pawie pióra itp. - 16\% wszystkich możliwych odpowiedzi), zamek w Malborku (12\%) oraz bitwa pod Grunwaldem (8\%). Respondenci wskazywali również na krucjaty i wyprawy wojenne Krzyżaków (7\%), chrześcijański charakter zgromadzenia zakonnego (5\%), postaci historyczne, jak Ulrich von Jungingen, Konrad Mazowiecki, Władysław Jagiełło (łącznie 3\%). Pojedyncze osoby wskazywały na powieść „Krzyżacy” Henryka Sienkiewicza bądź film Aleksandra Forda z roku 1960 oraz na niemiecki charakter zakonu (około $1 \%$ odpowiedzi w obu przypadkach). Analizując strukturę skojarzeń respondentów z zakonem krzyżackim, należy stwierdzić, że były to głównie odpowiedzi stereotypowe, nie wymagające znaczącej wiedzy na temat zakonu. Bardzo mało odpowiedzi można uznać za oryginalne. Autor zalicza do nich: inne miasta poza Malborkiem i Puckiem, budowę infrastruktury drogowej, sieci osadniczej oraz podanie takich wydarzeń, jak bitwa pod Świecinem z 17 września 1462 roku czy Hołd Pruski. Odpowiedzi te zaklasyfikowano jako inne. Zdaniem autora, wysoki odsetek badanych (53\%), którzy nie potrafili podać czterech skojarzeń, wskazuje na ich duże braki w wiedzy historycznej i ogólnej. Zadanie przed jakim stanęli respondenci było tym prostsze, że ankietowane osoby mieszkają na terenie dawnego państwa zakonnego. Ponadto, niedaleko Pucka, w województwie pomorskim, znajdują się atrakcyjne turystycznie zamki pokrzyżackie w Gniewie czy Bytowie. Co ciekawe, jedynie 5 osób miało skojarzenia związane z ruinami zamku krzyżackiego w Pucku. Może to świadczyć o braku powiązania historii lokalnej i powszechnej w świadomości większości ankietowanych. Na tle badanej grupy osób pozytywnie wyróżniała się młodzież szkolna, która nie miała problemu z podaniem czterech skojarzeń związanych z zakonem.

W pytaniu czwartym, ankietowane osoby miały odpowiedzieć na pytanie: „Czy zwiedzałeś/aś kiedykolwiek jakiś obiekt/y krzyżacki/e?” Struktura odpowiedzi przedstawia się następująco: $76 \%$ badanych osób odpowiedziało twierdząco, $20 \%$ negatywnie, a $4 \%$ odpowiedziało „nie wiem”. Respondenci poproszeni o doprecyzowanie jaki/e obiekt/y zwiedzali, najczęściej podawali zamek w Malborku (87,5\% badanych). Jedynie 3\% ankietowanych wymieniło inne zamki: w Kwidzynie, Toruniu i w Gniewie oraz Grunwald, który jest miejscem bitwy, a nie konkretnym obiektem wzniesionym przez zakon krzyżacki. Cztery 


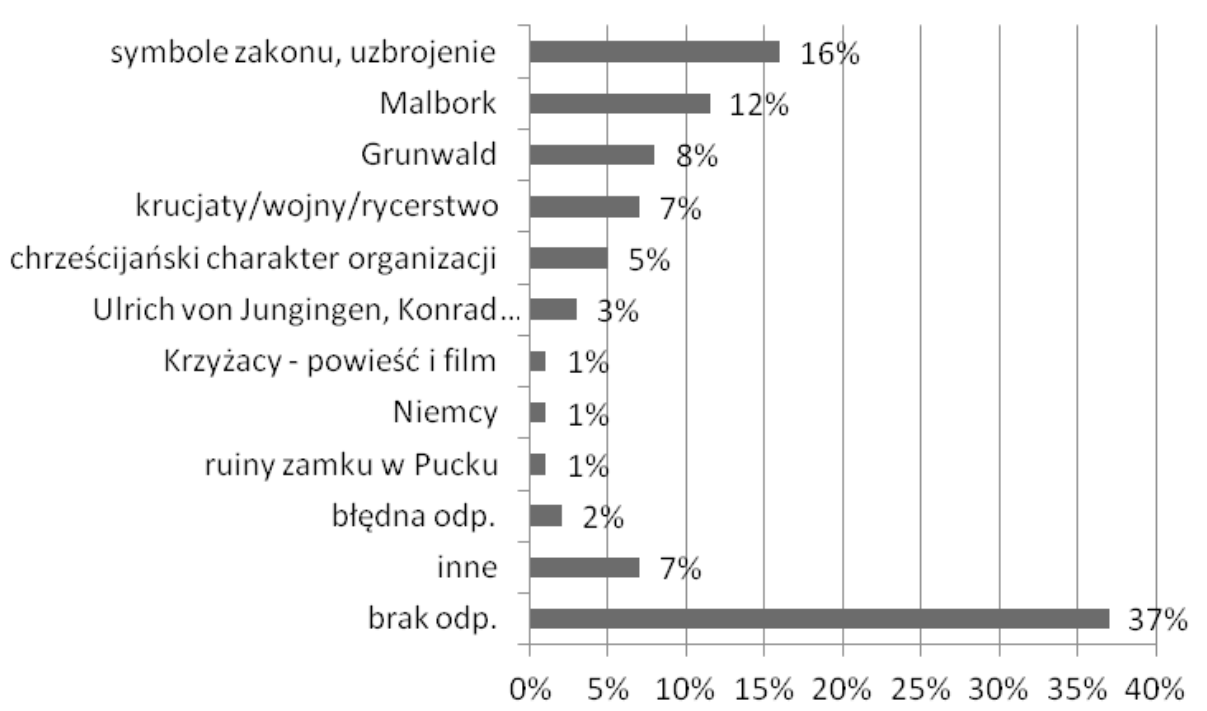

Rys. 3. Struktura procentowa deklarowanych skojarzeń respondentów z zakonem krzyżackim

Źródło: opracowanie własne na podstawie danych ankietowych

procent ankietowanych zadeklarowało wizytę $\mathrm{w}$ innym zamku, nie precyzując jego lokalizacji. Trzy i pół procent respondentów, którzy odpowiedzieli pozytywnie na zadane pytanie, nie potrafiło podać nazwy lub lokalizacji zwiedzanego obiektu. Pozostałe odpowiedzi zaklasyfikowano jako błędne lub „brak odpowiedzi”. Ani jeden z ankietowanych nie podał żadnego kościoła gotyckiego, bramy miejskiej, ratusza lub fragmentów obwarowań miejskich wybudowanych przez Krzyżaków. Wskazuje to jednoznacznie, że respondenci utożsamiają budownictwo zakonu z zamkami średniowiecznymi. Ciekawie wypada także porównanie odpowiedzi respondentów z wynikami analizy pytania trzeciego, gdzie zapytano o skojarzenia z zakonem. W pytaniu czwartym znacznie większa liczba osób wymieniła zamek w Malborku jako zwiedzany obiekt pokrzyżacki niż w pytaniu trzecim, gdzie trzeba było podać dowolne skojarzenie z zakonem krzyżackim.

Pytanie piąte dotyczyło znajomości Szlaku Polskich Zamków Gotyckich, łączącego wybrane i zagospodarowane zamki dawnego państwa zakonnego. Łącznie skupia on 12 obiektów znajdujących się w granicach Polski w następujących miejscowościach: Bytów, Malbork, Sztum, Kwidzyn, Olsztyn, Nidzica, Ostróda, Lidzbark Warmiński, Kętrzyn, Ryn, Gniew, Nowe nad Wisłą. Rozkład odpowiedzi prezentuje rys. 4. Ponad połowa ankietowanych (53\%) nie słyszała o szlaku, $1 / 3(33 \%)$ zadeklarowała znajomość szlaku, 13\% ankietowanych było niezdecydowanych, a $1 \%$ respondentów nie potrafił udzielić odpowiedzi. 


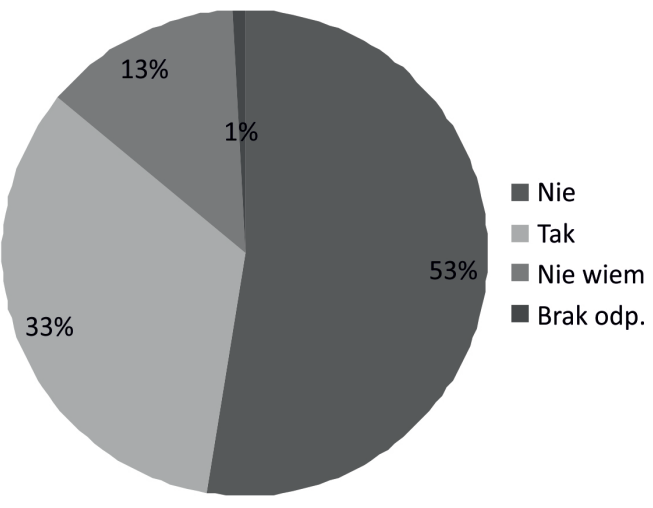

Rys. 4. Struktura odpowiedzi respondentów na pytanie o znajomość Szlaku Zamków Gotyckich

Źródło: opracowanie własne na podstawie badań ankietowych

Respondenci, którzy słyszeli o Szlaku Zamków Gotyckich, poproszeni o wyliczenie obiektów leżących na jego trasie, najczęściej wymieniali zamek w Malborku. Zdecydowanie rzadziej pojawiały się inne zamki: w Bytowie, Kwidzynie i Gniewie. Największy odsetek negatywnych odpowiedzi zanotowano w grupie najmłodszych respondentów (poniżej 20 lat), co wynika z jednej strony z dużej liczebności tej grupy w badanej populacji, a $z$ drugiej strony jest efektem niewielkiego zainteresowania i słabą wiedzą ogólną młodzieży w zakresie atrakcji turystycznych północnej Polski. Poziom wiedzy respondentów o Szlaku Polskich Zamków Gotyckich należy określić jako słaby. Wynikać to może z jednej strony z braku zainteresowania dziedzictwem kulturowym i atrakcjami turystycznymi, ale może być również efektem niewystarczającej promocji i niedofinansowania informacji turystycznej i organów zarządzających Szlakiem Polskich Zamków Gotyckich.

W kolejnym pytaniu respondenci byli poproszeni o samodzielną ocenę własnego poziomu wiedzy na temat historii i dziedzictwa kulturowego państwa zakonnego (w skali od 1 do 5, gdzie 1 - najsłabsza ocena, 5 - najlepsza ocena) oraz oceny działalności zakonu krzyżackiego w średniowieczu, na obszarze dzisiejszej Polski ( 1 - źle, 5 - dobrze). Swoją wiedzę na temat historii i dziedzictwa zakonu, respondenci w większości oceniali nisko. Najczęściej padały oceny od 1 do 3 . Odpowiedziało tak łącznie $89 \%$ ankietowanych, przy czym odpowiedzi te rozłożyły się mniej więcej równomiernie, od $26 \%$ do $33 \%$ na każdą z trzech najniższych rang (rys. 3). Tak słaba ocena wiedzy dotyczącej zakonu krzyżackiego wynika prawdopodobnie z braku zainteresowania tą częścią historii naszego kraju. W podpunkcie b) dotyczącym oceny działalności zakonu krzyżackiego w średniowieczu, najczęściej padały oceny krytyczne. Aż 83\% respondentów oceniło działalność zakonu w najniższych przedziałach, tj. od 1 do 3 (rys. 5). 


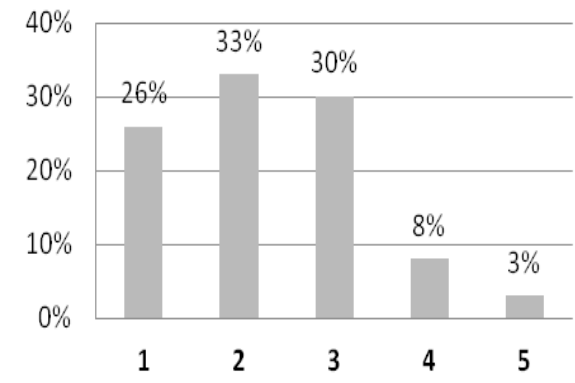

$\mathbf{A}$

Rys. 5. Rozkład odpowiedzi respondentów na pytanie o ocenę poziomu wiedzy respondentów na temat historii i dziedzictwa zakonu krzyżackiego w Polsce (A) i ocenę działalności zakonu krzyżackiego w średniowieczu na obszarze dzisiejszej Polski (B)

Krytyczna ocena działalności krzyżaków przez ankietowane osoby, wynika w dużej mierze z postrzegania działalności zakonu krzyżackiego jako organizacji szkodzącej ówczesnemu Królestwu Polskiemu, poprzez dyplomację, zbrojne podboje i wojny. W mniejszym stopniu brano pod uwagę działalność gospodarczą, osadniczą czy kulturową zakonników na podbitych terenach.

W pytaniu nr 7 respondenci mieli za zadanie ocenić w skali od 1 do 5 atrakcyjność turystyczną dziedzictwa pokrzyżackiego w Polsce oraz stopień wykorzystania dziedzictwa zakonu dla rozwoju turystyki w Polsce. Rozkład odpowiedzi prezentuje rys. 6 .
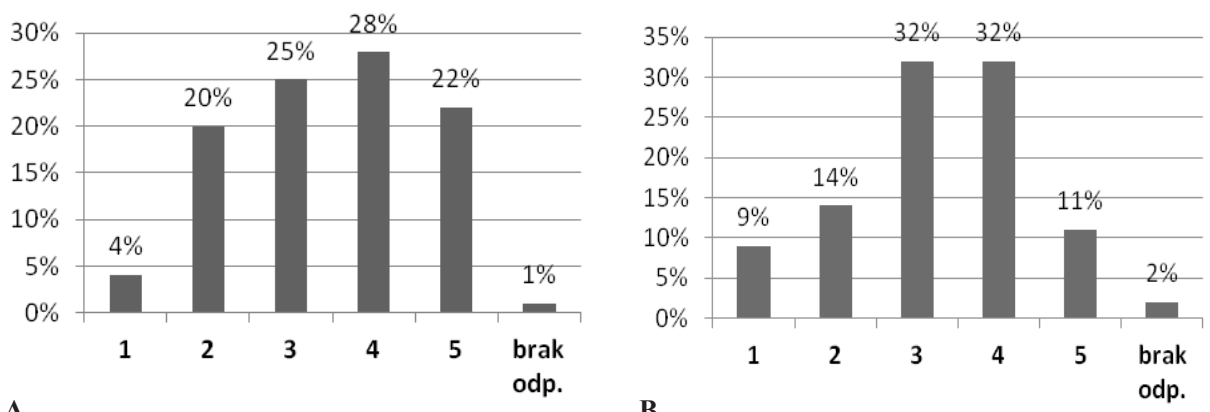

Rys. 6. Rozkład odpowiedzi respondentów na pytanie o ocenę atrakcyjności turystycznej dziedzictwa pokrzyżackiego w Polsce (A) oraz stopień wykorzystania dziedzictwa zakonu dla rozwoju turystyki w Polsce (B)

Źródło: opracowanie własne na podstawie danych ankietowych 
Odpowiedzi ankietowanych osób należy uznać za zróżnicowane. Połowa respondentów oceniła atrakcyjność dziedzictwa pokrzyżackiego dobrze lub bardzo dobrze (50\%), łącznie z oceną średnią daje to $75 \%$ wszystkich odpowiedzi. Najniższe oceny ( 1 i 2 ) przyznało $24 \%$ badanych. W uproszczeniu można przyjąć, że ankietowani uważają dziedzictwo kulturowe zakonu za atrakcyjne turystycznie. Druga część pytania dotyczyła oceny stopnia wykorzystania dziedzictwa pokrzyżackiego dla rozwoju turystyki. W tym przypadku rozkład odpowiedzi był mniej wyrównany. Najwyższą ocenę przyznało $11 \%$ badanych, ocenę 4 i 3 po $32 \%$ respondentów, a dwie najniższe rangi przyznało łącznie 23\% ankietowanych. Trzy najwyższe rangi przyznało $75 \%$ ankietowanych, czyli dokładnie tyle samo ile w przypadku oceny atrakcyjności dziedzictwa. Zasadnicze różnice polegają na dwukrotnie mniejszej liczbie wskazań najwyższej rangi i ponad dwukrotnie wyższej liczbie wskazań dla rangi najniższej w przypadku oceny wykorzystania turystycznego dziedzictwa. Analiza struktury odpowiedzi nasuwa wniosek, że zdaniem ankietowanych dziedzictwo pokrzyżackie jest atrakcyjne, ale w pewnym stopniu nadal stanowi niewykorzystany potencjał, który można lepiej przystosować dla pełnienia funkcji turystycznej.

W pytaniu nr 8 respondenci mieli za zadanie wymienić 5 zabytków pokrzyżackich w Polsce. Zgeneralizowany rozkład odpowiedzi ankietowanych przedstawiono na rys. 7. Łącznie respondenci mogli podać 1285 odpowiedzi (257x 5), z czego de facto udzielono 526, a więc mniej niż połowę $(642,5)$ możliwych. Pięćdziesiąt pięć osób nie odpowiedziało wcale na zadane pytanie, bądź nie potrafiło wymienić poprawnie ani jednego obiektu pokrzyżackiego $(21 \%$ wszystkich respondentów). Wskazuje to jednoznacznie na słabe rozeznanie w historii i tematyce dziedzictwa pokrzyżackiego. Osoby które najczęściej udzielały błędnych i niepełnych odpowiedzi to głównie respondenci w grupach wiekowych 41-50, 51-60, 61 i więcej. Jedynie w grupie młodzieży szkolnej odpowiedzi były właściwe i wyczerpujące, co należy tłumaczyć obecnością zagadnień związanych z zakonem krzyżackim na lekcjach historii. Należy uznać, że osoby poniżej 20. roku życia mają wystarczającą wiedzę w zakresie obiektów pokrzyżackich, a osoby starsze mają duże trudności, by wymienić pięć zamków bądź innych budowli pokrzyżackich. Rozkład odpowiedzi zaprezentowano na rys. 7. Wyraźnie dominująca w strukturze odpowiedzi jest pozycja Malborka jako największego i najbardziej znanego zamku wybudowanego przez zakon szpitalników Najświętszej Marii Panny (15\% wszystkich możliwych odpowiedzi). Kolejne miejsca zajęły obiekty w Gniewie, Toruniu i Bytowie. Zamki w Gniewie i Bytowie są położone na obszarze województwa pomorskiego, a więc niedaleko od miejsca realizacji badania. Ruiny zamku w Toruniu znajdują się w dużym mieście, które znane jest ze swoich zabytków średniowiecznych. Mimo prośby o podanie obiektów pokrzyżackich znajdujących się poza Puckiem, 18 osób (niecałe 1,5\% wszystkich odpowiedzi) wymieniło ruiny zamku w swoim mieście. Mimo, iż Grunwald nie 
jest obiektem pokrzyżackim, a miejscem rozegrania bitwy w której zakonnicy wzięli udział oraz trudno uznać odpowiedź „Gdańsk” za w pełni właściwą, autor zdecydował się nie umieszczać tych odpowiedzi w kategorii „inne”. Do grupy tej ze względu na znikomą liczbę powtarzających się odpowiedzi, zaliczono natomiast zamki lub ich pozostałości zlokalizowane w: Szczytnie, Giżycku, Sztumie, Lęborku, Morągu, Nidzicy, Grudziądzu, Człuchowie, Golubiu-Dobrzyniu, Olsztynku, Ełku, Radzyniu Chełmińskim, Świeciu. Kilka osób wymieniło również Królewiec (dzisiejszy Kaliningrad) jako miejsce związane z zakonem krzyżackim.

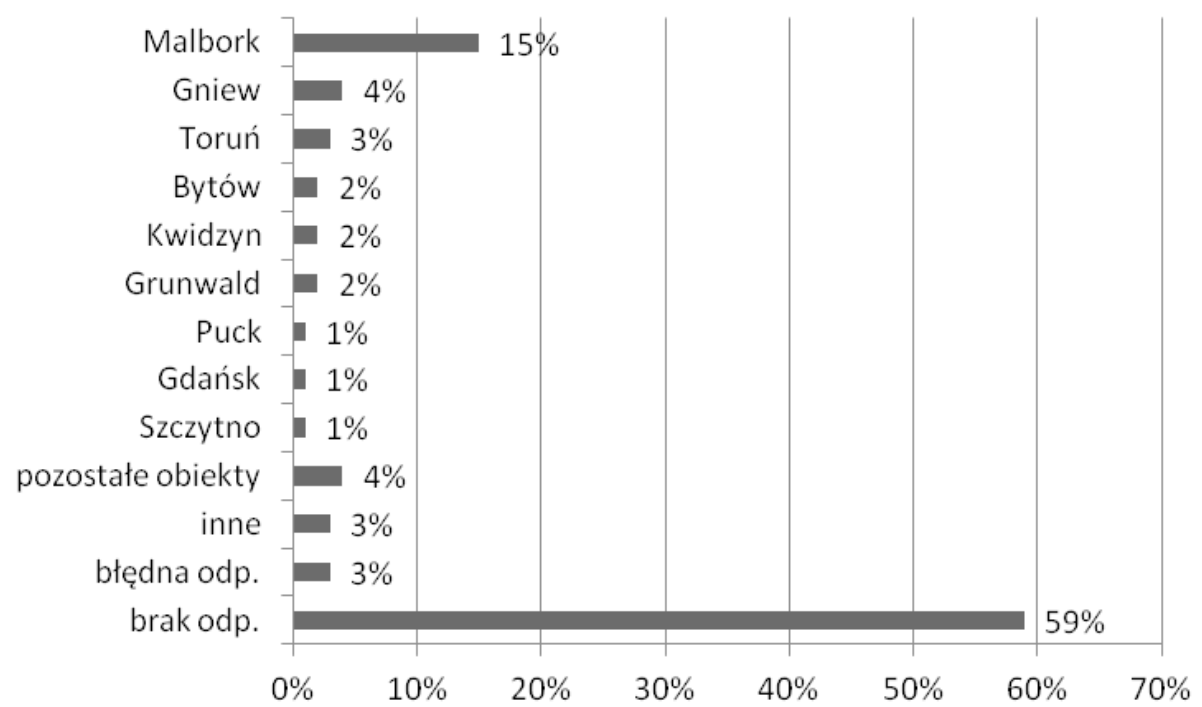

Rys. 7. Rozkład procentowy odpowiedzi respondentów na pytanie o znane obiekty pokrzyżackie w obecnych granicach Polski

Źródło: opracowanie własne na podstawie badań ankietowych

Analiza odpowiedzi wskazuje na fakt, że ankietowane osoby utożsamiają obiekty pokrzyżackie głównie z zamkami, w mniejszym stopniu zdając sobie sprawę, że zakonnicy wznieśli też szereg innych obiektów, jak choćby kościoły, bramy miejskie itd. Kolejna prawidłowość widoczna w odpowiedziach ankietowanych osób, wymienianie przede wszystkim obiektów znajdujących się w dobrej kondycji technicznej bądź chociaż częściowo zagospodarowanych i przystosowanych do obsługi ruchu turystycznego (Toruń i Radzyń Chełmiński). Jest to zjawisko naturalne, gdyż sława i renoma takich miejsc jest znacznie większa niż obiektów znajdujących się w stanie kompletnej ruiny.

Ankietowane osoby na pytanie nr 9 dotyczące tego, czy działalność zakonu krzyżackiego na terenach należących dziś do Polski miała swoje dobre strony, 
w większości (44\%) odpowiedziały „nie wiem”. Druga pod względem liczebności grupa respondentów (31\%) udzieliła odpowiedzi twierdzącej, 23\% badanych odpowiedziało „nie”, a 2\% nie udzieliło odpowiedzi na pytanie. Wśród osób, które dostrzegają pozytywne aspekty działalności zakonu, najczęściej padały odpowiedzi: rozwój wsi i miast (33\% ankietowanych, obecność zabytków pokrzyżackich, a więc działalność budownicza (16\%), ogólny rozwój gospodarczy i rozwój infrastruktury (po 10\%). Trzydzieści jeden procent badanych osób nie potrafiło sprecyzować dobrych stron gospodarowania zakonników na obecnych terytoriach Polski. Wniosek płynący z analizy struktury odpowiedzi na pytanie nr 9 jest taki, że tylko $1 / 3$ respondentów (31\%) dostrzega pozytywne aspekty działalności Krzyżaków, co świadczy generalnie o negatywnym postrzeganiu zakonu lub braku wiedzy bądź refleksji większości respondentów w tej kwestii.

Kolejna grupa pytań, od 10 do 13, dotyczyła roli zakonu krzyżackiego i wiedzy respondentów na temat dziejów Pucka. W pytaniu nr 10 ankietowane osoby zostały poproszone o podanie wieku oraz dokładnej daty lokacji Pucka. Ponad połowa ankietowanych osób (51\%) nie odpowiedziało na pytanie, $29 \%$ osób podało właściwy wiek, a $20 \%$ udzieliło odpowiedzi błędnej. W przypadku pytania o dokładną datę lokacji, rozkład odpowiedzi był podobny. Pięćdziesiąt trzy procent ankietowanych nie odpowiedziało, 30\% podało prawidłową datę (1348), a 17\% udzieliło odpowiedzi błędnej. Podobny odsetek prawidłowych odpowiedzi wskazuje, że w większości te same osoby znały zarówno rok, a w konsekwencji wiek lokacji miasta. Tak wysoki odsetek poprawnych odpowiedzi może wynikać z tego, że obecne władze Pucka wprowadziły zwyczaj odgrywania hymnu miasta nie w samo południe, ale o godzinie $13^{48}$, co ma przypominać datę lokacji miasta. Większość poprawnych odpowiedzi udzieliła młodzież szkolna.

W pytaniu nr 11 poproszono respondentów o podanie pięciu największych atrakcji turystycznych Pucka w kolejności od najatrakcyjniejszej do najmniej atrakcyjnej. Rozkład odpowiedzi był zróżnicowany. Wskazania respondentów $\mathrm{w}$ liczbach bezwzględnych przedstawiono $\mathrm{w}$ tab. 2, a strukturę procentową na rys. 8. Największy odsetek respondentów wskazał na farę jako na główną atrakcję Pucka (14\%). Na kolejnych czterech miejscach znalazły się następujące atrakcje: port $(11 \%)$, molo (10\%), rynek ( $9 \%)$ i muzeum puckie $(9 \%)$.

Odpowiedzi respondentów można podzielić na dwie grupy. Do pierwszej zaliczają się atrakcje antropogeniczne, elementy dziedzictwa kulturowego (fara, rynek itd.), drugą grupę tworzą atrakcje związane z nadbrzeżnym położeniem miasta (molo, port itd.). Co ciekawe, po zsumowaniu elementów dziedzictwa kulturowego średniowiecza (fara, rynek, ruiny zamku) oraz atrakcji związanych z morzem (port, molo, zatoka, pielgrzymka rybacka) okazało się, że większa liczba wskazań dotyczyła pierwszej grupy $-26 \%$ ogólnej liczby odpowiedzi, wobec $23 \%$ dla grupy drugiej. 
Tabela 2

Rozkład odpowiedzi respondentów w liczbach bezwzględnych na pytanie o największe atrakcje turystyczne Pucka uszeregowane od najbardziej do najmniej atrakcyjnej

\begin{tabular}{|c|c|c|c|c|c|c|}
\hline \multirow{2}{*}{$\begin{array}{c}\text { Treść } \\
\text { odpowiedzi }\end{array}$} & \multicolumn{5}{|c|}{ Ranga } & \multirow{2}{*}{ Razem } \\
\hline & 1 & 2 & 3 & 4 & 5 & \\
\hline Fara & 67 & 35 & 43 & 21 & 12 & 139 \\
\hline Rynek & 19 & 38 & 26 & 27 & 11 & 132 \\
\hline Ruiny zamku & 3 & 13 & 3 & 4 & 5 & 119 \\
\hline Muzeum & 21 & 36 & 27 & 24 & 11 & 15 \\
\hline Ratusz & 3 & 1 & 4 & 6 & 1 & 31 \\
\hline Port & 29 & 45 & 32 & 28 & 5 & 178 \\
\hline Molo & 55 & 34 & 19 & 16 & 8 & 121 \\
\hline Zatoka & 17 & 0 & 8 & 4 & 2 & 28 \\
\hline Inne & 18 & 23 & 31 & 20 & 39 & 131 \\
\hline $\begin{array}{l}\text { Brak } \\
\text { odpowiedzi }\end{array}$ & 25 & 32 & 64 & 107 & 161 & 389 \\
\hline Razem & 144 & 134 & 154 & 175 & 217 & 1285 \\
\hline
\end{tabular}

Wytłuszczonym drukiem zaznaczono odpowiedzi zaklasyfikowane jako dziedzictwo kulturowe średniowiecza.

Źródło: opracowanie własne na podstawie danych ankietowych.

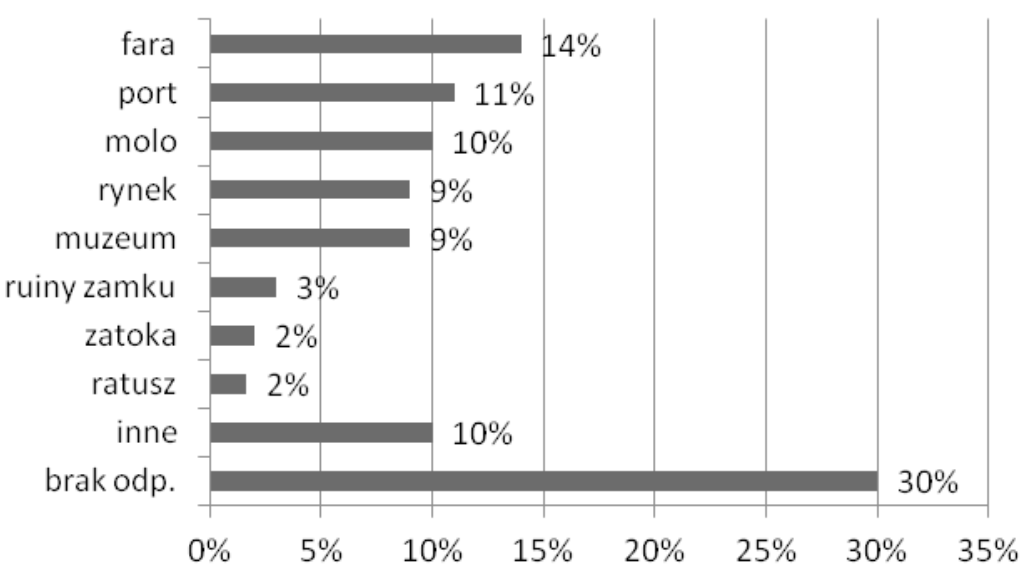

Rys. 8. Struktura procentowa odpowiedzi respondentów na pytanie o największe atrakcje turystyczne Pucka uszeregowane od najbardziej do najmniej atrakcyjnej

Źródło: opracowanie własne na podstawie danych ankietowych 
Po dodaniu muzeum (9\%), dystans ten jeszcze się powiększa. Taki rozkład odpowiedzi wskazuje jednoznacznie, że mieszkańcy Pucka na pierwszym miejscu stawiają walory kulturowe swojego miasta, a dominującą rolę w tym zakresie odgrywa dziedzictwo pokrzyżackie (średniowieczne).

Pewne znaczenie dla takiej struktury odpowiedzi może mieć również fakt, że Puck nie jest najbardziej znanym kąpieliskiem w okolicy, większą renomą w tym względzie cieszy się niedalekie Władysławowo i miejscowości położone na Mierzei Helskiej.

Pytania zapisane pod nr 12 miały na celu sprawdzenie wiedzy mieszkańców Pucka na temat historii, dziedzictwa kulturowego i jego roli w budowaniu atrakcyjności i promocji miasta. Procentowy rozkład odpowiedzi badanych osób zaprezentowano w tab. 3. Pierwsze dwa pytania dotyczyły historii Pucka i związków zakonu krzyżackiego z miastem. Niespełna 1/4 respondentów odpowiedziała niezgodnie z prawdą, że Puck w przeszłości nie należał do państwa zakonnego, co po dodaniu $14 \%$ osób niezdecydowanych daje łącznie ponad $1 / 3$ ogółu badanych (36\%). W drugim pytaniu - „Czy w Pucku znajdował się zamek krzyżacki?”, $28 \%$ badanych odpowiedziało negatywnie, co po dodaniu osób niezdecydowanych daje blisko połowę badanej grupy (49\%). Tak wysokie odsetki błędnych odpowiedzi wskazują na dużą ignorancję historyczną i niewiedzę badanych. Negatywną ocenę stanu wiedzy respondentów pogłębia fakt, że do czasów obecnych zachowały się ruiny zamku pokrzyżackiego, które nie zostały włączone w strukturę jakiegoś współczesnego budynku. Negatywne odpowiedzi najczęściej podawały osoby z wykształceniem średnim i po 50. roku życia. Najmniejszy odsetek błędnych odpowiedzi zanotowano wśród najmłodszej grupy wiekowej.

Następne pytanie dotyczyło kwestii ewentualnej rekonstrukcji zamku w Pucku. Zdecydowana większość respondentów (59\%) popiera takie działania, a 22\% badanych jest przeciwna takim zabiegom. Zdaniem autora taki rozkład odpowiedzi zgodny jest z powszechną opinią społeczeństwa, że więcej korzyści może przynieść obiekt zrekonstruowany, niż zachowany w postaci tak zwanej „trwałej ruiny". Głosy przeciwne padały wśród osób, które twierdziły, że miasto nie ma pieniędzy na takie inwestycje (co nie wyklucza poparcia samej idei rekonstrukcji obiektu).

Na pytanie, czy układ przestrzenny Pucka stanowi atrakcję turystyczną, ponad połowa (53\%) badanych osób przytaknęła, dodając, że są z niego bardzo dumni. Zdaniem autora duży wpływ na znaczny odsetek takich odpowiedzi ma estetyczny widok dużego rynku puckiego, poddanego procesom rewaloryzacyjnym w 2011 roku.

Kolejne dwa pytania dotyczyły kwestii promocji miasta poprzez dziedzictwo kulturowe zakonu krzyżackiego. Respondenci stwierdzili, że władze miasta tylko w niewielkim stopniu wykorzystują dziedzictwo pokrzyżackie do promocji Pucka (15\% wszystkich odpowiedzi) i wyrazili ubolewanie $\mathrm{z}$ tego powodu. Zdaniem 
Tabela 3

Struktura procentowa odpowiedzi respondentów na pytania dotyczące historii, dziedzictwa kulturowego i jego roli w budowaniu atrakcyjności i promocji miasta

\begin{tabular}{|l|c|c|c|c|c|}
\hline \multirow{2}{*}{ Treść pytania } & \multicolumn{3}{|c|}{ Odpowiedzi (\%) } & \multirow{2}{*}{ Razem } \\
\cline { 2 - 5 } & Tak & Nie & $\begin{array}{c}\text { Nie } \\
\text { wiem }\end{array}$ & $\begin{array}{c}\text { Brak } \\
\text { odp. }\end{array}$ & \\
\hline $\begin{array}{l}\text { Czy Puck położony był w obrębie } \\
\text { państwa krzyżackiego? }\end{array}$ & 62 & 22 & 14 & 2 & 100 \\
\hline $\begin{array}{l}\text { Czy w Pucku znajdował się zamek } \\
\text { krzyżacki? }\end{array}$ & 49 & 28 & 21 & 2 & 100 \\
\hline $\begin{array}{l}\text { Czy zamek w Pucku należy zre- } \\
\text { konstruować? }\end{array}$ & 59 & 22 & 17 & 2 & 100 \\
\hline $\begin{array}{l}\text { Czy układ przestrzenny Pucka } \\
\text { stanowi atrakcję turystyczną? }\end{array}$ & 53 & 28 & 17 & 2 & 100 \\
\hline $\begin{array}{l}\text { Czy miasto wykorzystuje dziedzi- } \\
\text { ctwo pokrzyżackie jako element } \\
\text { promocji? }\end{array}$ & 15 & 57 & 25 & 2 & 100 \\
\hline $\begin{array}{l}\text { Czy jesteś za wykorzystaniem } \\
\text { dziedzictwa pokrzyżackiego do } \\
\text { promocji Pucka? }\end{array}$ & 69 & 18 & 12 & 1 & 100 \\
\hline
\end{tabular}

Źródło: opracowanie własne na podstawie danych ankietowych.

mieszkańców miasta jest to niewykorzystany potencjał turystyczny, który mógłby przyciągnąć turystów do Pucka. Jednocześnie ponad $2 / 3$ badanych (69\%) postuluje wykorzystywanie dziedzictwa kulturowego zakonu krzyżackiego do promocji miasta. Jeśli zamek w Pucku zostanie poddany rekonstrukcji, odsetek osób twierdzących, że lokalny samorząd nie wykorzystuje dziedzictwa pokrzyżackiego do promocji miasta na pewno znacznie się obniży. Negatywna opinia większości respondentów na temat działań promocyjnych władz Pucka, nie do końca jest zgodna z prawdą, gdyż obecne walory miasta są dobrze oznaczone w terenie i opisane, a pucka fara, ruiny zamku czy układ przestrzenny miasta są uwzględniane w materiałach promocyjnych (fot. 2).

Ostatnie, 13 pytanie miało na celu określenie poziomu deklarowanego patriotyzmu lokalnego. Na pytanie: „Czy jesteś dumny/a z tego, że mieszkasz w Pucku?", 45\% respondentów odpowiedziało twierdząco, 33\% negatywnie, zaś $18 \%$ było niezdecydowanych (w obu tych grupach znaczny odsetek stanowiły osoby mieszkające w okolicach Pucka), 4\% badanych nie odpowiedziało na pytanie.

Na rys. 9 zaprezentowano rozkład odpowiedzi na pytanie o przyczynę odczuwania dumy z miasta. Prawie połowa respondentów mieszkających w samym Pucku (48\%) odpowiedziała, że jest dumna z miejsca swojego zamieszkania. 

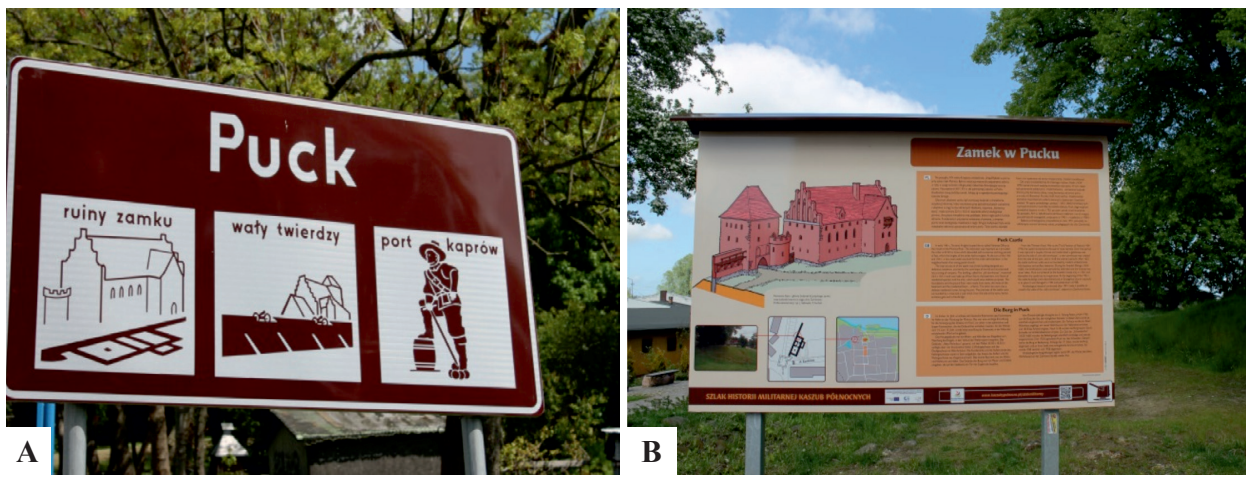

Fot. 2. Elementy promocji wizualnej i informacji turystycznej dziedzictwa kulturowego w Pucku

A - tablica informacyjna przed wjazdem do Pucka od strony ul. 10 lutego

B - tablica informacyjna przy ruinach zamku puckiego przy ul. Zamkowej

\section{fot. L. Musiaka}

Ankietowani swoją odpowiedź motywowali głównie tym, że miasto jest spokojne $(17 \%)$, co ma duże znaczenie w zatłoczonym w sezonie letnim regionie nadmorskim, posiada dogodną lokalizację (13\%), ponadto doceniona była estetyka i wygląd miasta (14\%). Stosunkowo często (15\%) padała również odpowiedź, że dana osoba odczuwa dumę, ponieważ urodziła się w tym mieście i utożsamia się z nim. Najrzadziej respondenci podawali jako motywację rolę Pucka w historii Polski (5\%) oraz atrakcje dla mieszkańców i turystów, jakie są dostępne w mieście $(2 \%)$. Po przeanalizowaniu odpowiedzi ankietowanych osób należy stwierdzić, że odsetek zarówno osób starszych, jak i młodszych, które mieszkają w Pucku, deklaruje dumę z miasta i patriotyzm lokalny.

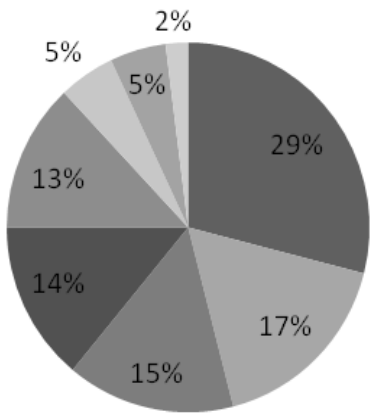

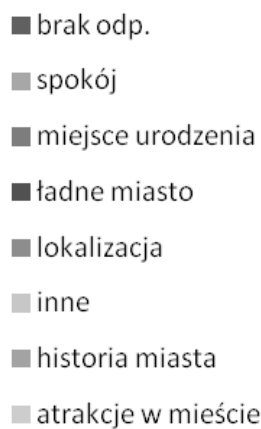

Rys. 9. Rozkład procentowy odpowiedzi respondentów na pytanie o przyczyny deklarowanej dumy z mieszkania w Pucku

Źródło: opracowanie własne na podstawie badań ankietowych 


\section{Podsumowanie}

Jednym z celów badania było określenie poziomu wiedzy i świadomości historycznej mieszkańców Pucka oraz poczucia ich patriotyzmu lokalnego. Wyniki przeprowadzonych analiz należy uznać za niezadowalające. Zakres wiedzy respondentów o miejscu swojego zamieszkania jest niewystarczający. W przypadku deklarowanego poziomu patriotyzmu lokalnego sytuacja wygląda znacznie lepiej. Wyniki badań potwierdzają wcześniejsze analizy autora zrealizowane w latach 2008-2010 w wybranych szkołach średnich sześciu miast: Bytowa, Gniewu, Lidzbarka Warmińskiego, Rynu, Reszla i Nidzicy (łącznie 616 osób). Badana młodzież szkolna dostrzega istotną rolę dziedzictwa kulturowego w kształtowaniu pozytywnego wizerunku miejsca zamieszkania i zdaje sobie sprawę z jego wartości kulturowej i historycznej. Na pytanie: „Czy jesteś dumny/a z zamku i swojego miasta", pozytywną odpowiedź udzieliła prawie połowa respondentów (48,7\% badanych). W strukturze procentowej jest to prawie identyczna wartość, jaka osiągnięta została w Pucku. Nie jest to wysoki wskaźnik dla miejscowości Pomorza, Warmii i Mazur, postrzeganych jako atrakcyjne turystycznie (których ranga turystyczna jednakże nie zawsze równa jest randze Pucka). Wpływ na taki poziom dumy lokalnej badanych zbiorowości ma szereg czynników, jak: młody wiek respondentów, warunki i jakość życia, poziom zamożności, wartości i wiedza przekazywane w rodzinie i wiele innych (Musiaka 2014). Wyniki badań autora są również zbieżne z analizami prof. Izabeli Lewandowskiej z Olsztyna, która uznała, że ,świadomość regionalna młodego pokolenia istnieje, lecz nie jest zbyt wysoka. Spowodowane jest to przede wszystkim słabymi więziami intelektualnymi, czyli niską wiedzą o regionie oraz więziami emocjonalnymi, które niezbyt głęboko organizują osobowość uczniów". Równocześnie autorka zauważa, że młodzież jest „bardzo emocjonalnie związana z przyrodą i krajobrazem regionu warmińsko-mazurskiego" (Lewandowska 2002, s. 349). W przypadku Pucka, gdzie badano zarówno młodzież szkolną, jak i osoby starsze, duży wpływ na deklarowany poziom odczuwanej dumy z miasta ( $48 \%$ ankietowanych) ma oprócz wieku, także miejsce zamieszkania. Nie wszyscy respondenci mieszkają w Pucku, lecz w okolicznych miejscowościach. Zdaniem autora, rzeczywisty poziom patriotyzmu wśród lokalnej społeczności jest znacznie wyższy.

Podstawowym celem badania było uzyskanie informacji dotyczących poziomu wiedzy mieszkańców Pucka na temat dziedzictwa zakonu krzyżackiego oraz sposobów i możliwości jego wykorzystania. Poziom wiedzy respondentów ogółem na temat historii zakonu krzyżackiego można określić jako niski. Wyróżniającą się na tym tle grupą była młodzież szkolna, zapewne z racji konieczności uczęszczania na lekcje historii. W przypadku znajomości dziedzictwa pokrzyżackiego na terenach dawnego państwa zakonnego, wyniki badań również należy określić jako niezadowalające, tym bardziej, że były one przeprowadzane 
w mieście leżącym niegdyś w obrębie państwa krzyżackiego, czego namacalne dowody przetrwały w tkance miejskiej do dziś. Podobnie skojarzenia respondentów związane z zakonem krzyżackim zazwyczaj bazowały na ogólnej wiedzy o Krzyżakach, jak elementy wizualnej identyfikacji zakonników, militarny i jednocześnie chrześcijański charakter zakonu, zamek w Malborku czy bitwa pod Grunwaldem.

Szczególnie interesujące dla autora były zagadnienia związane ze znajomością historii, dziedzictwa kulturowego i jego roli w budowaniu atrakcyjności i promocji Pucka. Struktura odpowiedzi badanych osób wskazuje na ich dużą ignorancję historyczną i niewiedzę (na tym tle po raz kolejny pozytywnie odznaczyła się grupa młodzieży szkolnej). Jednocześnie mieszkańcy Pucka i okolic uważają miasto za atrakcyjne turystycznie. Zdaniem autora, w pierwszym rzędzie o atrakcyjności miasta decyduje nadmorskie położenie, a także bliskość aglomeracji trójmiejskiej, Półwyspu Helskiego i rejonu Kaszub. Z pewnością można tu również dodać lokalne tradycje kulturowe i możliwości uprawiania aktywnego wypoczynku. Bardzo ciekawa jest również historia miasta. Jednakże jak pokazują wyniki badań ankietowych, znaczna część mieszkańców miasta i okolic uważa, że o atrakcyjności Pucka decydują w znacznym stopniu walory antropogeniczne średniowiecza - pucka fara, rynek lokacyjny i oczywiście ruiny zamku pokrzyżackiego. Mieszkańcy popierają wykorzystywanie elementów dziedzictwa kulturowego do promocji miasta i twierdzą, że znaczny potencjał kulturowy nie jest w pełni wykorzystywany w celach promocyjnych. Bardzo mocnym impulsem do rozwoju funkcji turystycznej miasta byłaby rozważana obecnie rekonstrukcja zamku, W większości popierana przez respondentów (głosy przeciwne wynikały głównie z obawy o brak funduszy na realizację zadania). Według strategii rozwoju miasta, rekonstrukcja miałaby polegać na udostępnieniu „pozostałości zamku krzyżackiego poprzez odsłonięcie i rewitalizację zabytkowych murów, zagospodarowanie otoczenia w sposób umożliwiający przebywanie turystów, poprawę dostępności poprzez budowę parkingu" (Strategia ..., s. 129). Pomijając sporne kwestie doktryny konserwatorskiej dotyczące rekonstrukcji obiektów zabytkowych pozostających w ruinie, inwestycja taka z pewnością przyciągnęłaby do miasta znaczną grupę turystów w sezonie letnim. Przy odpowiednim zarządzaniu obiektem i organizacji imprez historycznych oraz propagowaniu tzw. historii żywej, wartości te mogłyby wzrosnąc jeszcze bardziej. Jak podaje portal historyczny ${ }^{3}$, „,władzom miasta zależy na stworzeniu atrakcji, z której sami mieszkańcy będą dumni”. W ramach strategii rozwoju Pucka planuje się także odsłonić relikty pierwotnego ratusza, stworzyć model 4D miasta $\mathrm{z}$ okresu średniowiecza i makietę planu miasta z 1810 roku na rynku, a także utworzyć ścieżkę turystyczno-edukacyjną

${ }^{3} \mathrm{http}: / /$ strefahistorii.pl/article/1391-w-pucku-zaplanowano-odbudowe-zamku-bazy-floty-zygmunta-iii (dostęp: 4.04.2016). 
i zagospodarować plac północny wraz z naprawą okalającego muru. Wszelkie działania podejmowane $\mathrm{w}$ celu promocji i popularyzacji dziedzictwa kulturowego średniowiecza i innych epok należy uznać za bardzo cenną inicjatywę. Oprócz możliwości uzyskania doraźnych korzyści płynących ze zwiększenia skali ruchu turystycznego w Pucku, z pewnością przyczynią się one do poszerzenia wiedzy mieszkańców miasta i turystów w tym zakresie.

\section{Podziękowanie}

Autor artykułu wyraża podziękowanie studentom II roku studiów licencjackich kierunku Studia Regionalne za wykonaną pracę w ramach ćwiczeń terenowych „Działalność człowieka w regionie".

\section{LITERATURA}

Altkorn K., 1994, Marketing $w$ turystyce, Wydawnictwo Naukowe PWN, Warszawa, $203 \mathrm{~s}$.

Babbie E., 2003, Badania spoteczne w praktyce, Wydawnictwo Naukowe PWN, Warszawa, $659 \mathrm{~s}$.

Grzegorz M., 2014, Słownik historyczno-geograficzny okręgu puckiego komturstwa gdańskiego w średniowieczu, Wydawnictwo Uniwersytetu Kazimierza Wielkiego, Bydgoszcz, $103 \mathrm{~s}$.

Kruppe J., Milewska M., 2014, Dzieje zamku w Pucku, Warszawa, 195 s.

Lewandowska I., 2002, Świadomość historyczna i regionalna licealistów: wnioski z badań w regionie warmińsko-mazurskim, [w:] Kubis B., (red.) Edukacja historyczna a wspótczesność. Księga jubileuszowa dedykowana Profesorowi dr hab. Adamowi Suchońskiemu w czterdziestolecie pracy dydaktycznej i naukowej oraz z okazji siedemdziesiatych urodzin, Wydawnictwo Uniwersytetu Opolskiego, Opole, s. 335-350.

Musiaka Ł., 2014, Dziedzictwo i wspótczesne wykorzystanie średniowiecznych zamków państwa zakonu krzyżackiego a świadomość historyczna uczniów wybranych szkót województw warmińsko-mazurskiego i pomorskiego, rozdział w monografii, Ryn, (w druku).

Musiaka $亡 ., 2015$, Medieval heritage of small towns in the State of the Teutonic Order in the register of monuments, [w:] Sobczyński M., Rykała A. (red.), Geographical-political aspects of the transborder conservation of natural and cultural heritage, „Region and Regionalism", 12(1), s. 219-238.

Starski M., 2011, Dzieje rynku w Pucku, [w:] Archeologia pradziejowa i średniowieczna. Archeologia Polski, Światowit, Rocznik Instytutu Archeologii Uniwersytetu Warszawskiego, t. 8 (2009-2010), Pascykuł B, Warszawa, s. 149-161.

Sypek A., Sypek R., 2003, Zamki i obiekty warowne Pomorza Gdańskiego, Almapress, Warszawa, $160 \mathrm{~s}$.

Śliwiński B., 1998, Dzieje Pucka w świetle najstarszych źródet pisanych (do 1308 r.), [w:] Groth A., (red.), Historia Pucka, Gdańsk, s. 55-68.

Wasilewska E., 2008, Statystyka opisowa nie tylko dla socjologów, Wydawnictwo SGGW, Warszawa, $268 \mathrm{~s}$. 


\title{
Źródla internetowe
}

http://muzeumpuck.pl/ (dostęp: 04.04.2016).

http://www.nid.pl/pl/ (dostęp: 04.04.2016).

http://www.polskawliczbach.pl/ (dostęp: 04.04.2016).

http://www.puck.uw.edu.pl/ (dostęp: 04.04.2016).

http://strefahistorii.pl/article/1391-w-pucku-zaplanowano-odbudowe-zamku-bazy-floty-

-zygmunta-iii (dostęp: 04.04.2016).

\section{Pozostałe źródła}

„Wyniki badań percepcji dziedzictwa zakonu krzyżackiego w Pucku w 2015 roku” - opracowanie wykonane w ramach ćwiczeń terenowych „Działalność człowieka w regionie" przez studentów II roku studiów licencjackich na kierunku Studia Regionalne.

Strategia Rozwoju Gminy Miasta Puck na lata 2015-2025, http://miastopuck.pl/wp-content/uploads/strategia_v.4.pdf (dostęp: 04.04.2016).

\section{PERCEPTION OF THE CULTURAL HERITAGE OF THE TEUTONIC ORDER ON THE EXAMPLE OF PUCK}

\begin{abstract}
One of the important places on the map of the former State of the Teutonic Order on the Baltic Sea shore was Puck. Nowadays, there are: parish church, ruins of the castle of the Teutonic Knights and the clearly visible spatial layout of the chartered town with a large market preserved. Except natural attractiveness of the seashore location, elements of the medieval heritage play an important role in the promotion of the town, as well as in shaping a sense of pride and patriotism of the local residents. In the presented article the author attempts to determine the level of knowledge of the people living in the area of the former Teutonic State in the field of history and material cultural heritage of the Teutonic Order. The basis of analyzes were the results of a survey carried out in Puck on May 2015.
\end{abstract}

Keywords Perception, cultural heritage, Teutonic Order, Puck.

Dr Łukasz Musiaka Katedra Geografii Politycznej i Studiów Regionalnych Wydział Nauk Geograficznych Uniwersytet Łódzki 